\title{
Microcystis Toxica sp. nov. a poisonous alga from the Transvaal and Orange Free State
}

(Summary of paper read May 16th 1945 before the Royal Society of South Africa and to be spublished in the Transactions

of that Society).

by

EDITH L. STEPHENS,

(Botanical Department, University of Cape Town).

This alga first came into notice after the building of the great Vaaldam in the Transvaal ( 5 miles long, capacity 220 thousand million gallons), which was completed in 1938. Stock were dying along the bank by the end of 1940. By the end of 1942 a vigorous water-bloom of this alga extended over $98 \%$ of the dam. Thousands of sheep and cattle died; many other kinds of animals found dead nearby were probably killed by the alga, but feeding experiments were confined to sheep and cattle. These experiments conclusively proved the alga to be responsible. The living species contains one of the most potent and destructive liver poisons known, but the dried alga is much less toxic. Animals drinking at a mildly infected „pan” (i.e. a shallow sheet of water, varying in size from a pool to a small lake) may not die, but only show a falling-off in condition. In the past, various ,,pans" have acquired a bad reputation among farmers as containing "bad" water for stock; the presence of this alga is the probable cause. It is widespread in S. E. Transvaal and N. E. Orange Free State, but is so far not recorded elsewhere. Treatment with copper sulphate has proved successful in keeping it in check at Vaaldam.

The alga is closely related to $M$. aeruginosa, but constitutes a separate species. The colonies average $1 \mathrm{~mm}$. in diameter; when mature, they consist of a peripheral network of strands and balls of close-packed cells and are of all sorts of extraordinary shapes. It differs from $M$. aeruginosa in its larger size, the peripheral network of cells, the toxicity, and the distinctive odour and colour in decay. 